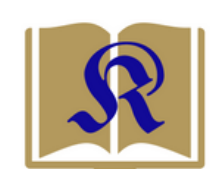

KURIOS
KURIOS

(Jurnal Teologi dan Pendidikan Agama Kristen)

ISSN 2615-739X (print), 2614-3135 (online)

Vol. 5, No. 2, Oktober 2019 (125-138)

http://www.sttpb.ac.id/e-journal/index.php/kurios

\title{
Politik Identitas Etnis Toraja sebagai Masalah Teologis: Kasus di Kabupaten Kolaka, Sulawesi Tenggara
}

\author{
Frans Paillin Rumbi \\ Sekolah Tinggi Agama Kristen Negeri Toraja \\ fransrumbi24@gmail.com
}

\begin{abstract}
The issue to be examined is identity politics by Torajanese in Kolaka Regency and how to highlight it in terms of Christian political theology. To obtain the data, the writer uses a grounded theory type of qualitative research method. From the results of the research, it appears that identity politics is used to: First, to cultivate compassion or solidarity. Second, realizing the interests of certain elements in the realm of practical politics, especially related to the position in the system of government. Those research show that there is a gap in vision among the community, this situation also triggered internal conflicts between them. The problem needs to be addressed immediately, specifically the author highlights it from the perspective of political theology. Conflict can be overcome if the conflicting parties hold a dialogue to prioritize life values such as love, justice and peace.
\end{abstract}

\begin{abstract}
Abstrak
Masalah yang hendak dikaji dalam artikel ini ialah politik identitas orang Toraja di Kabupaten Kolaka dan bagaimana menyorotinya dari segi teologi politik Kristen. Untuk memeroleh data, maka penulis menggunakan metode penelitian kualitatif jenis grounded theory. Dari hasil penelitian, tampak bahwa politik identitas digunakan untuk: Pertama, membudayakan belarasa atau solidaritas. Kedua, mewujudkan kepentingan oknum tertentu pada ranah politik praktis terutama terkait dengan kedudukan dalam sistem pemerintahan. Kedua temuan memperlihatkan adanya kesenjangan visi dalam komunitas, situasi itu turut memicu konflik internal di antara mereka. Masalah tersebut perlu segera diatasi, secara khusus penulis menyorotinya dari perspektif teologi politik. Konflik dapat diatasi jika pihak-pihak yang bertikai mengadakan dialog mengutamakan nilai-nilai kehidupan seperti kasih, keadilan, dan damai sejahtera.
\end{abstract}

https://doi.org/10.30995/kur.v4i1.104

\section{Pendahuluan}

Identitas merupakan salah satu penciri khusus seseorang dan kelompok. Bagi kelompok atau komunitas, politisasi identitas dibutuhkan untuk memperkuat kolektivitas. Namun masing-masing anggota perlu mengarahkan kelompoknya menghindar dari sikap eksklusif 
berlebihan sebab dapat menimbulkan sikap intoleran dan primordial. Penelitian sebelumnya menunjukkan bahwa politik identitas telah menumbuhkan semangat kebangsaan Indonesia tetapi di sisi lain menimbulkan masalah kebangsaan, sebagaimana hal tersebut ditunjukkan oleh Mifdal Zusron Alfaqi. ${ }^{1}$ Sementara itu, Kristianus, menunjukkan politik identitas digunakan saat pemilihan kepala daerah (Pilkada) di Kalbar untuk mendapatkan kekuasaan serta menguatkan solidaritas kelompok. ${ }^{2}$

Politik identitas berbeda dari identitas politik. Politik identitas (political of identity) menekankan mekanisme politik pengorganisasian identitas sebagai sumber dan sarana politik, sedangkan identitas politik (political identity) lebih pada dasar-dasar yang menentukan tujuan komunitas politik. ${ }^{3}$ Bagi para pengagumnya politik identitas dipandang sebagai solusi terhadap kebuntuan narasi besar (grand narrative) terkait kebebasan, toleransi dan kebebasan bermain baik dengan komunitasnya maupun kelompok lain. ${ }^{4}$ Tetapi idealisme sering tidak beriringan dengan realita. Identitas seringkali dipolitisir untuk menonjolkan perbedaan pendapat, membatasi kebebasan berkeyakinan serta membatasi perkembangan budaya.

Kasus-kasus politik identitas yang sempat mencuat dipermukaan, antara lain: Pertama, kontestasi Pemilihan Gubernur Jakarta (2016). Pada kasus ini identitas keagamaan dipolitisir untuk menjatuhkan lawan politik, dengan harapan dapat memperoleh kekuasaan. Pihak yang kalah menilai proses pemilihan tidak fair dan menciderai nilai-nilai demokrasi. Tampak kekalahan meninggalkan luka mendalam, indikasinya selalu muncul sikap membandingbandingkan gubernur terpilih dengan pendahulunya. Menilai gubernur yang baru kurang tanggap terhadap kebutuhan masyarakat. Sebaliknya kelompok pemenang, hidup dalam euforia sebab merasa superior. Bagi mereka kritikan dari kelompok yang kalah, merupakan bentuk kecemburuan.

Apabila aspek negatif dari penilaian kedua kelompok ditekankan, maka dapat membahayakan kehidupan bersama. Oleh karena itu, terlepas dari penilaian subjektif ataupun objektif, kekecewaan dan kegembiraan berlebihan harus diatasi demi mencegah "menjamurnya" kecurigaan dan kebencian.

Kedua, Politik identitas menjelang pemilihan Presiden 2019. Kedua calon presiden berusaha mendapatkan simpati kaum muslim sebagai pemilik suara mayoritas. Tim sukses menyusun strategi dengan merangkul tokoh-tokoh agama dan partai politik yang memiliki basis massa cukup kuat di kalangan umat muslim.

\footnotetext{
${ }^{1}$ Mifdal Zusron Alfaqi, "Memahami Indonesia Melalui Perspektif Nasionalisme, Politik Identitas, Serta Solidaritas," Jurnal Pendidikan Pancasila dan Kewarganegaraan 28, no. 2 (2015): 111-116.

2 Kristianus, "Politik dan Startegi Budaya Etnik dalam Pilkada Serentak di Kalimantan Barat," Politik Indonesia: Indonesian Political Science Review 1, no. 1 (2016): 87-101.

${ }^{3}$ Muhtar Habodin, "Menguatnya Politik Identitas Dalam Ranah Lokal," Jurnal Studi Pemerintahan 3, no. 1 (2012), 119.

${ }^{4}$ Muhammad Habibi, “Analisis Politik Identitas di Indonesia,” Maret 2017, 4 diakses 11 Oktober 2018, https://osf.io/preprints/inarxiv/pey72.
} 
Jika isu identitas digunakan untuk menumbuhkembangkan kebencian serta politik transaksional, maka langkah-langkah yang digunakan bukan contoh yang baik bagi demokrasi di Indonesia. Perbedaan perlu dikelola untuk mencegah konflik horizontal dalam negara.

Politik identitas merupakan ancaman bagi konsensus bersama para founding fathers Indonesia. Berangkat dari hal tersebut, penulis berusaha mengkaji politik identitas, khususnya kasus etnis Toraja di Kabupaten Kolaka. Pada konteks ini, identitas digunakan untuk membentuk kerukunan-kerukunan yang berdasarkan asal-usul kampung maupun wilayah administratif pemerintahan. Tujuan awal pendirian kerukunan cukup baik, namun dalam perjalanannya ada oknum-oknum yang ingin memanfaatkan kerukunan untuk kepentingan politis. Akibatnya terjadi perpecahan dalam organisasi maupun kehidupan bersama di masyarakat.

Klaim benar-salah memupuk kebencian di antara pihak yang berselisih, dan secara tidak langsung menghambat cita-cita hidup bersama. Berdasarkan kasus ini, maka pertanyaan penelitian yang dijaukan ialah: Bagaimana menjawab politik identitas etnis Toraja dengan menggunakan sudut padang teologi politik? Pertanyaan ini diharapkan menjadi kekhasan penelitian, yang berbeda dengan penelitian-penelitian yang telah disebutkan di atas.

\section{Metode Penelitian}

Penelitian ini menggunakan metode penelitian kualitatif model grounded theory. ${ }^{5}$ Model grounded theory berusaha mengembangkan teori berdasarkan data penelitian yang diperoleh. Oleh karena itu yang dicari ialah substansi. Tantangan yang dihadapi ialah seorang peneliti dituntut untuk peka terhadap perubahan perilaku maupun gagasan pada konteks yang sedang diteliti. Metode grounded theory dianggap dapat membantu menemukan aspek-aspek yang mendorong etnis Toraja membentuk kerukunan untuk menegaskan identitasnya. Di samping itu, membantu mengetahui persoalan mendasar dari usaha politisasi identitas etnis.

\section{Memaknai Identitas Melalui Kerukunan}

Etnis Toraja yang dimaksud dalam artikel ini ialah orang Toraja yang datang dan hidup menetap di Kabupaten Kolaka, Propinsi Sulawesi Tenggara. Mereka berasal dari Kabupaten Tana Toraja, Toraja Utara, Luwu dan Luwu Utara di Sulawesi Selatan, serta dari Kabupaten Mamasa di Sulawesi Barat. Di Kolaka, pola pemukiman mereka cenderung mengikuti jenis profesi yang ditekuni. Petani tinggal di sekitar daerah pertanian dan perkebunan. Pegawai pemerintah tinggal di perkotaan ataupun sekitar tempat kerja. Sementara karyawan tambang, memilih tinggal disekitar perusahaan.

Kesibukan bekerja serta jarak pemukiman yang berjauhan memengaruhi intensitas komunikasi di antara orang Toraja. Kondisi demikian dipandang dapat mengikis semangat kebersamaan serta nilai-nilai kultural orang Toraja. Merenggangkan hubungan serta menggeser kolektifitas ke pola hidup individualis. Sadar terhadap dampak negatif yang

\footnotetext{
${ }^{5}$ Anselm Strauss dan Juliet Corbin, "Metodologi Grounded Theory Ulasan Singkat," in Handbook Of Qualitative Research, ed. Norman K. Denzin dan Yvonna S. Lincoln (Yogyakarta: Pustaka Pelajar, 2009), 349-364.
} 
timbul, orang Toraja mulai membentuk organisasi atau kerukunan-kerukunan, sebagai wadah mempertahankan kolektifitas dan solidaritas.

Tercatat telah terbentuk kurang lebih 18 kerukunan orang Toraja di Kab. Kolaka. Uniknya, hampir semua anggota keluarga terdaftar pada dua atau lebih kerukunan. Hal itu dapat terjadi karena pasangan suami-istri berasal dari daerah berbeda, atau pun karena orang tua mereka berasal dari kampung berbeda.

Apabila diklasifikasikan, ada dua jenis kerukunan, yakni menurut asal wilayah administratif dan kerukunan berdasarkan etnis. Kerukunan berdasarkan wilayah administratif antara lain, kerukunan keluarga Sangalla', Bastem dan Makale. Karakteristik kerukunan ini ialah anggotanya berasal dari daerah yang sama, dan masih terikat hubungan kekerabatan. Kerukunan berdasarkan etnis seperti Kasiturusanna Sang Torayan (Kastor) dan Persatuan Masyarakat Toraja Indonesia (PMTI).

Setiap kerukunan memiliki karakteristik. Kerukunan Makale menekankan solidaritas pada berbagai sendi kehidupan, seperti: menolong anggota yang hidup dalam kemiskinan, saling membantu saat menghadapi rambu tuka' dan rambu solo.' Di samping itu, mengarahkan anggota agar aktif dalam pembangunan di Kabupaten Kolaka.

Pengurus sadar bahwa mempertahankan kebersamaan bukan hal mudah khususnya saat menyadari andanya perbedaan agama, strata sosial maupun tingkat kesejahteraan. Berhadapan dengan tantangan ini, pengurus membangun kebersamaan dengan semangat pluralis. Di mana anggota kerukunan diajak untuk saling mengakui dan menerima satu sama lain. Sikap pluralis dipercaya mampu mencegah konflik internal. Sementara itu, untuk meredam keinginan memertahankan sistem kasta atau strata sosial, maka ditempuh langkah-langkah yang menegaskan bahwa pola kehidupan baru dimulai di daerah yang baru. Dikembangkan juga perasaan sepenanggungan di tanah rantau. Tantangan makin berat, karena ada oknum yang berusaha mempertahankan status kebangsawanannya (puang, ma'dika, ambe dan parengge) serta status berdasarkan kekayaan yang dimiliki (kasugiran).

Kerukunan Keluarga Bastem (KKB) terdiri dari orang Toraja yang berasal dari Bastem di Kab. Luwu. Dari nama organisasi, jelaslah cita-cita kerukunan ini yakni mengembangkan semangat kekeluargaan. Tujuan tersebut dapat dicapai melalui aksi-aksi konkret seperti membantu keluarga yang berduka (rambu solo') maupun akan melaksanakan perayaan sukacita (rambu tuka).

Terkait perbedaan agama dan sikap tenggang rasa dibina melalui perayaan hari-hari besar keagamaan secara bergantian. Semetara itu, semangat kekeluargaan diwariskan kepada anakanak dengan cara membawa mereka saat pertemuan anggota maupun melalui program beasiswa berprestasi. Kerukunan Bastem tidak hanya berorientasi ke dalam, kebersamaan dengan anggota masyarakat lain dibangun melalui kegiatan bakti sosial.

Kerukunan Sangalla' membina kebersamaan melalui keterlibatan saat menyelenggarakan pernikahan maupun menghadapi dukacita. Selain itu, pengurus berusaha agar setiap kebijakan yang diambil dapat diterima semua pihak. Pengurus menghindari keputusan politik yang 
memecah belah, seperti mendukung tokoh politik tertentu saat pemilihan kepala daerah (pilkada) atau pemilihan legislatif (pileg).

Meskipun kerukunan-kerukunan sudah berusaha mewujudkan kebersamaan, hal tersebut dianggap belum cukup mempersatukan semua orang Toraja. Atas dasar itu, mereka yang dituakan dalam kerukunan serta para pengurus sepakat membentuk kerukunan yang lebih besar. Mula-mula dibentuk Kastor untuk mempersatukan orang Toraja baik yang berasal dari Kab. Tana Toraja dan Toraja Utara, Mamasa, maupun Luwu.

Harapan tersebut ternyata jauh dari kenyataan karena terjadi konflik kepentingan yang cukup kompleks. Ada oknum yang ingin memanfaatkan Kastor untuk kepentingan pribadi dan kelompoknya, misalnya mendukung salah satu calon kepala daerah, tanpa perlu mempertimbangkan secara objektif rekam jejaknya serta visi misi sang calon bagi masyarakat Kab. Kolaka. Friksi memuncak ketika sebagian anggota memutuskan untuk keluar dari Kastor lalu membentuk organisasi bernama Forum Komunikasi Masyarakat Toraja (Fokmat).

Setelah beberapa tahun, kedua organisasi sepakat membangun relasi baru. Adapun langkah-langkah yang ditempuh ialah mengadakan pertemuan untuk perdamaian. Disepakati bahwa Kastor dan Fokmat perlu dibubarkan, sebagai gantinya dibentuk organisasi baru bernama Persatuan Masyarakat Toraja Indonesia (PMTI).

Pengurus PMTI dipilih dari unsur pengurus lama (Kastor dan Fokmat). Namun dalam perjalanannya persoalan klasik tak mampu dihindari. PMTI diterpa perpecahan karena ulah segelintir orang yang tidak puas terhadap struktur kepengurusan. Mereka membentuk organisasi tandingan dengan "menghidupkan" kembali Kastor. Menurut oknum yang pro PMTI, ada politisasi dibalik pemilihan nama Kastor. Nama itu dipilih karena dahulu kastor memiliki basis massa yang cukup kuat. Sebagai bagian dari sosialisasi dan mencari simpati orang Toraja yang lain, oknum-oknum pada kelompok yang baru berusaha membangun isu negatif. Dalam mengoposisikan kedua kelompok, anggota kastor mengklaim bahwa PMTI merupakan organisasi elite, sedangkan Kastor merupakan organisasi rakyat menengah ke bawah.

Praktis orang Toraja yang tidak mengetahui duduk persoalan, bingung karena masingmasing kelompok mengklaim sebagai organisasi resmi. Perselisihan makin tajam karena kedua pengurus saling sindir, bahkan saling lapor pada kepolisian.

Ketua PMTI Kab. Kolaka menjelaskan konflik terjadi karena oknum tertentu menekankan sikap primordial dengan sistem feodalnya sebagai syarat kepemimpinan. Dengan kata lain, pemimpin harus dipilih berdasarkan status sosialnya di kampung Toraja). Oknum yang bersangkutan lupa bahwa terlah terjadi perubahan konteks. Kini mereka hidup dengan sistem sosial yang berbeda.

Cara lain yang ditempuh untuk memecah persatuan ialah menyebarkan hoaks bahwa prosedur pemilihan pengurus tidak sesuai dengan kesepakatan. Padahal proses pemilihan sudah sesuai dengan prosedur. Di mana pemilihan melibatkan pengurus kerukunan wilayah bahkan menyertakan tokoh-tokoh masyarakat Toraja di Kolaka. 
Beberapa hal yang menyebabkan konflik pada organisasi etnis ialah: Pertama, anggotanya tidak mengerti tujuan pembentukan kerukunan serta kurangnya sosialisasi. Kedua, ada oknum yang berusaha memperjuangkan kepentingan politiknya. Ketiga, ada upaya mengarahkan orang Toraja untuk mendukung pada salah satu calon kepala daerah. Keempat, kecewa karena tidak terpilih sebagai salah seorang pengurus PMTI.

\section{Ambivalensi Politik Identitas}

\section{Identitas Politik Demi Kebersamaan}

Identitas politik yang nampak melalui pembentukan kerukunan adalah cara mempertahankan eksistensi kelompok etnis (ethnic group) di tempat yang baru. Tetapi bukan berarti orang Toraja Sekalipun menerapkan begitu saja (taken for granted) pola kehidupan dari tempat asal di Toraja. Mereka memberi pola, ciri serta makna baru sesuai dengan konteks yang dihadapi.

Kerukunan mempertemukan cara merasa, semangat untuk hidup bersama serta membangun interaksi sosial berlandaskan semangat kebangsaan, etnisitas, agama, kelas sosial, generasi, lokalisme ataupun kelompok sosial yang memiliki karakteristik budaya masing-masing. ${ }^{6}$ Menurut Hall identitas budaya nampak melalui wujud maupun proses menjadi (identity as becoming). ${ }^{7}$ Sementara itu, dari segi wujud orang Toraja melestarikan kultur asalnya dengan cara membangkitkan memori kolektif. Metode mengingat yang digunakan adalah mengungkit aspek pertalian darah atau hubungan kekeluargaan sebagai pemersatu. Di samping itu, membangkitkan kenangan tentang peristiwa masa lampau di mana mereka pernah terlibat bersama. Dari segi proses, prosesnya cukup fleksibel, menyesuaikan dinamika sosio, politik dan budaya di Kolaka.

Mencermati tujuan dan realisasi kegiatan, nampak ciri yang paling menonjol adalah membangun kebersamaan melalui komunikasi sosial. Komunikasi sosial sebagai salah satu cara menciptakan suasana yang menghibur, nyaman, dan tenteram baik dengan diri sendiri maupun bersama yang lain. Serentak dengan itu, disosialisasikan norma-norma budaya Toraja kepada anggota dewasa dari kerukunan maupun mewariskan nilainya kepada anak-anak. ${ }^{8}$ Merujuk pada teori interaksi Gilin dan Gilin, pola komunikasi kerukunan orang Toraja termasuk proses asosiatif sebab yang dikerjakan ialah mewujudkan kerjasama dan asimilasi. ${ }^{9}$ Kerukunan fokus pada meningkatkan kebersamaan melalui hubungan kekeluargaan. Mengembangkan kepedulian atau belarasa saat menghadapi peristiwa insidental. Kebersamaan turut dibina melalui bakti sosial. Sedangkan sikap saling menghargai ditanamkan ke anak-anak melalui program beasiswa berprestasi.

\footnotetext{
${ }^{6}$ Nararya Narottama, A A Ayu Arun, dan Suwi Arianty, "Proses Pembentukan Identitas Budaya Nasional dan Promosi Pariwisata Indonesia di Eropa ( studi kasus diaspora bali di perancis )," Jurnal Kepariwisaatan dan Hospitalitas 1, no. 2 (2017): 185.

7 Ibid.

${ }^{8}$ Ira Mirawati, "Manajemen Komunikasi dan Perdamaian Antar etnis," dalam Komunikasi Kontekstual: Teori dan Praktik Komunikasi Kontemporer (Bandung: Remaja Rosdakarya, 2013).

${ }^{9}$ Ng. Philipus dan Nurul Aini, Sosiologi dan Politik (Jakarta: RajaGrafindo Persada, 2004), 23.
} 
Sekalipun identitas politik kerukunan bersifat eksklusif, tetapi mereka tetap berusaha supaya kebersamaan turut dirasakan oleh semua masyarakat. Argumentasi itu logis karena semakin banyak yang hidup rukun, maka semakin besar potensi memertahankan kedamaian. Bagaimanapun juga, perdamaian masyarakat dapat terwujud apabila kelompok-kelompok kecil membiasakan kebersamaan, lalu mengembangkannya pada masyarakat.

Catatan penting yang perlu diajukan yakni apakah terjadi pergeseran makna ataukah memang mereka tidak memiliki konsep yang jelas mengenai tujuan yang ingin dicapai? Memang ada pesan yang disampaikan melalui aksi atau tindakan simbolik. Namun belum diketahui seberapa besar pemahaman dan kebutuhan terhadap kebersamaan. Jika berangkat dari filsafat realisme George Herbert Mead tentang teori interaksionis simbolis, maka evaluasi dimulai dengan mengamati aktivitas kerukunan dan manfaatnya bagi anggota. Ada empat basis atau tahapan yang dapat diidentifikasi, yakni impuls, persepsi, manipulasi dan konsumasi. ${ }^{10}$ Pada konteks kerukunan, maka yang dilakukan adalah (1) Mengamati reaksi individu terhadap kebersamaan; (2) Pemikiran dan penilaian terhadap aksi bersama yang dilakukan untuk mengenali atau memilih ciri kebersamaan yang sungguh-sungguh dibutuhkan; (3) Menguji pola-pola kebersamaan dalam berbagai bentuk aksi sosial; (4) Mewujudkan kebersamaan yang diinginkan.

Kebersamaan bukan berarti bebas konflik, melainkan sebuah kewajaran jika terjadi intrik saat menyelaraskan ide. Akan tetapi perlu meminimalisir atau mengendalikan konflik supaya tidak meluas dan memecah kebersamaan. Terkait hal itu, perlu mengevaluasi kegiatan yang telah berlangsung.

\section{Politik Identitas Untuk Kepentingan Anggota Tertentu}

Politik identitas kerukunan cenderung menciptakan pola interaksi sosial yang eksklusif. Mau tidak mau mereka yang berkomitmen untuk membesarkan kelompok di pengaruhi sikap membedakan antara anggota dan bukan anggota, keluarga dan bukan keluarga, status puang dan orang biasa, beragama Kristen dan Islam, serta perbedaan lain. Memerhatikan kasus pada etnis Toraja, tampak oposisi agama dikelola dengan baik demi mewujudkan toleransi. Namun negatif yang muncul ialah terbatasnya kedewasaan berinteraksi, khususnya cara membangun relasi yang lebih dialogis. Bukan berdasarkan perbedaan melainkan ikatan batin sebagai sesama yang manusia yang wajib saling memerhatikan dan mendukung.

Perpecahan pada tubuh PMTI memperlihatkan aspek negatif politik identitas. Perpecahan - demikian juga yang terjadi pada kerukunan sebelumnya, Kastor dan Fokmat - menunjukkan adanya lingkaran setan berupa ketidaksadaran akan fungsi kerukunan bagi mereka. Kesannya, kerukunan diinginkan tetapi tidak ingin dialami atau dihayati sebagai milik bersama. Kerukunan tidak melebihi organisasi biasa, yang hanya dibentuk untuk kepentingan temporal.

Konflik sulit dicegah karena proses adaptasi tidak berjalan mulus. Kesepakatan membentuk PMTI tidak disertai kesadaran mengenai pergeseran yang cukup tajam pada dasar

${ }^{10}$ Georger Ritzer; Douglas J. Goodman, Teori Sosiologi Modern, Terj. Tri Wibowo Budi Santoso, 6 ed. (Jakarta: Kencana Prenada Media Group, 2007), 274-276. 
persatuan yakni ikatan kekeluargaan. PMTI tidak didasari oleh hubungan kekeluargaan melainkan semangat kedaerahan. Efek dominonya yakni, mereka yang ingin menonjolkan status sosial seakan mendapat ruang untuk memperlihatkan dirinya. Padahal konsep demikian tidak dapat dipaksakan, karena secara kultural masing-masing kampung/ wilayah adat di Toraja memiliki sistem dan model kepemimpinan tradisional yang berbeda. Pertaruhan utama dari kelompok yang ingin mengagungkan status sosial ialah harga diri dan hegemoni marga. Bagi mereka kesederajatan dan kekalahan ideologi memperlihatkan hilangnya pengakuan dan harga diri.

Sepertinya, masalah yang muncul pada PMTI tidak murni soal memimpin dan dipimpin. Usaha mereka menggiring kerukunan ke politik praktis, menciderai kehidupan bersama. Patut dicurigai apakah ada pertukaran antara organisasi dan kekuasaan? Hergveldt, Thompson dan Cook mengatakan orang yang merasakan dirinya mempunyai kekuasaan lebih besar, memiliki kemungkinan lebih besar menghubungkan hasil pertukarannya dengan tindakan atau interaksi pribadi. ${ }^{11}$ Secara matematis kerukunan memiliki posisi tawar yang tinggi. Jumlah massa yang besar sangat berharga bagi calon kepala daerah maupun calon legislatif. Harapan yang menyertai, suara dapat ditukar dengan jabatan, kekuasaan, proyek serta bantuan dana hibah.

Merujuk prosedur pemilihan tampaknya sudah sesuai prosedur sebab yang memilih merupakan wakil dari setiap kerukunan-kerukunan serta tokoh masyarakat. Jadi tidak ada alasan menggugat proses pemilihan karena kasus ketidakadilan. Jika teori John Rawls yang menjadi acuan, seharusnya tidak terjadi konflik. Menurut Rawls, keadilan adalah (1) setiap orang mempunyai hak yang sama atas kebebasan dasar yakni kebebasan politik di mana semua orang mendapat kesempatan memilih dan dipilih dalam jabatan publik. (2) ketimpangan sosial dan ekonomi dapat dihindari apabila menguntungkan semua orang dan semua orang memiliki kesempatan yang sama untuk menduduki posisi atau jabatan. ${ }^{12}$ Oknum yang kalah saat pemilihan pengurus kerukunan sesungguhnya telah mendapatkan hak dan kesempatan yang sama untuk dipilih dan memilih. Netralitas pengurus dan tua-tua yang hadir pun dapat dipertanggungjawabkan karena mereka duduk bersama dilandasi keinginan terwujudnya kebersamaan yang baru.

Jika dari pihak yang kalah berhembus isu bahwa sebagian pemilih merupakan pendukung pengurus terpilih, maka hal tersebut patut dikaji. Apakah benar telah berlangsung praktik demikian? Ataukah hanya bahasa manipulatif demi menarik simpatik dari anggota lain yang tidak mengetahui duduk persoalan. Terlepas dari itu, belum terlihat keterbukaan untuk saling menerima dari kedua pihak yang berkonflik untuk memperbaiki relasi. Masih-masing mempertahankan idenya. Pihak yang menang belum serius merangkul pihak yang kalah. Sementara itu pihak yang kalah sudah kehilangan trust. Kecurigaan dan kebencian mereka terlalu besar.

11 Ibid, 381.

12 John Rawls, Teori Keadilan: Dasar-dasar Filsafat Politik Untuk Mewujudkan Kesejahteraan Sosial Dalam Negara, Terj. Uzair Fauzan dan Heru Prasetyo (Yogyakarta: Pustaka Pelajar, 2006), 72. 
Kebuntuan komunikasi belum disertai keinginan menghadirkan mediator. Pengurus kerukunan belum menampakkan kepemimpinan yang mempersatukan. Belum ada usaha mendatangi pihak yang kalah untuk menyelesaikan masalah. Sebaliknya, pihak yang kalah tidak mau bertemu pengurus untuk menyampaikan aspirasinya. Lain kata, kedua pihak memertahankan arogansi. Faktor harga diri menghalangi keinginan untuk menciptakan perdamaian.

Faktor lain yang memengaruhi konflik adalah kepengurusan dipahami sebagai kepemilikan kekuasaan. Semakin tinggi posisi semakin besar kekuasaan yang diharapkan. Nampaknya kepemimpinan pada kerukunan dimaknai seperti kepemimpinan politis yang bersifat rantai komando, padahal struktur organisasinya bersifat kolektif. Artinya setiap pengambilan keputusan harus disepakati oleh semua pengurus bahkan beberapa keputusan penting harus melibatkan semua anggota kerukunan.

\section{Identitas Dalam Perspektif Iman Kristen}

Identitas kerukunan orang Toraja perlu disoroti dari perspektif teologi politik Kristen, bukan karena sebagian besar anggota kerukunan adalah warga gereja. Dalam perspektif yang positif, bangkitnya semangat identitas merupakan salah satu cara membangun kebersamaan atau kolektifitas. Di samping itu, dengan menyatukan orang Toraja dalam kerukunan, kohesi sosial yang terbentuk sedang mewariskan semangat dan nilai-nilai budaya. Situasi yang kurang lebih sama dijumpai pada teks-teks biblis tentang ide umat pilihan Allah dan gereja.

Identitas pengikut-pengikut Kristus dipelihara dan dipertahankan supaya pesan-pesan Injil Yesus Kristus yang disampaikan melalui tradisi lisan dapat diterima dan direfleksikan oleh umat. Konsep teologis lain yang menerangkan kebersamaan yakni koinonia dan communion. Koinonia dan communion bermakna partikularis dan universal. Makna partikular tidak menghalangi makna universal, justru sebagai batu loncatan menuju yang universal. Universalitas yang ingin diwujudkan berupa situasi yang melampaui diferensiasi dan separasi, tetapi sekaligus dapat hidup dalam perbedaan. ${ }^{13}$ Communion mengingatkan mengenai peristiwa perjamuan malam terakhir Yesus bersama murid-muridNya. Peristiwa yang dirayakan oleh gereja sebagai tanda peringatan atas kematian dan kebangkitanNya. Praktek religius itu menandakan penerimaan dan perdamaian Allah dengan manusia. Jadi pada peristiwa ada peragaan mengenai cara berbagi kehidupan kepada semua orang.

Gereja terbentuk bukan hanya untuk menampakkan identitas pengikut Kristus, tetapi untuk melaksanakan dengan serius missio Dei. Gereja harus menghidupi dan mewartakan nilai-nilai kehidupan yang diajarkan Kristus. Gereja sebagai persekutuan atau koinonia tidak berdiri sendiri karena dijiwai oleh diakonia dan oikonomia. ${ }^{14}$ Persekutuan memudahkan

\footnotetext{
${ }^{13}$ Felix Baghi, "Politik Sebagai Kejadian dan Etika Kebenaran (Alain Badiou dan Soal Universalisme)," dalam Allah Menggugat-Allah Menyembuhkan, Terj. Otto Gusti Maddung, Anselmus Meo dan Paul Budi Kleden (Maumere: Ledalero, 2012), 324.

${ }^{14}$ John Campbell-Nelson, "Demokrasi Sebagai Misi Gereja," in Teologi Politik: Panggilan Gereja di Bidang Politik Pascaorde Baru, ed. Julianus Mojau, Zakaria J. Ngelow dan John Campbell-Nelson (Makassar: OASE Intim, 2013), ...
} 
gereja terlibat dalam pelayanan kepada sesama yang membutuhkan serta mengupayakan penatalayanan demi kehidupan bersama untuk semua makhluk. Zakaria J. Ngelow menegaskan peran gereja mewartakan Injil Kerajaan Allah yang berisi kasih, keadilan dan damai sejahtera di tengah-tengah dunia sehingga berdampak pada perubahan cara hidup masyarakat, yang memungkinkan semua orang untuk bisa hidup bersama di Indonesia yang majemuk. $^{15}$

Meski demikian, gereja harus menyadari ancaman pengagungan identitas eksklusif. Sikap eksklusif menumbuhkan perasaan superior-inferior bahkan dapat mendorong legalisasi kekerasan dalam ruang pergaulan dengan yang lain. Menurut Gerrit Singgih, agar gereja terhindar dari sikap, maka perlu mengembangkan nilai-nilai universal serta menyingkirkan sikap yang terlalu menekankan identitas khusus. Identitas tetap dibutuhkan dalam mengembangkan nilai-nilai yang positif. ${ }^{16}$

Sejarah mencatat kehancuran bangsa Israel karena terlalu mengagungkan politik identitas, yakni ide umat pilihan Allah. Ada juga kelompok-kelompok yang gagal membangun kehidupan bersama karena mengagungkan identitasnya. Misalnya, kasus holocaust, berupa pembantaian terhadap orang Yahudi di kamp-kamp pengungsian oleh Nazi. Di Indonesia, banyak terjadi kerusuhan yang mengatasnamakan etnis dan agama. Kasus-kasus tersebut meninggalkan luka mendalam pada korban, bahkan kenangan buruk terwariskan pada generasi kedua dan ketiga pasca peristiwa.

Berhadapan dengan politik identitas, perlu mengikuti kesaksian Rasul Paulus tentang Yesus. Kehadiran Yesus memisahkan sekaligus memersatukan (Ef. 1:23). Seperti halnya konsep tubuh Kristus dalam 1 Korintus 12:24-25. Kedua hal itu tampil bersamaan dan dapat dibedakan. Keduanya dapat dipertahankan oleh gereja selama mampu menetralisir sikap negatif dan mengembangkan sikap yang positif. ${ }^{17}$

Kegagalan komunikasi dalam kerukunan yang ditandai dengan konflik, menunjukkan bahwa perdamaian perlu diusahakan secara internal. Perdamaian merupakan salah satu misi Allah yang harus dinyatakan oleh pengikut Kristus kepada dunia. Perdamaian dapat dilakukan apabila seseorang atau kelompok membebaskan diri dari prasangka negatif mengenai yang lain. Oleh sebab itu, perlu mengembangkan kesadaran menghargai diri dan orang lain bahkan alam ciptaan. ${ }^{18}$ Dari mana spirit ini dikembangkan? Gereja harus menjiwai karya Yesus Kristus yang mendamaikan Allah dengan manusia. Melalui Yesus, Allah tidak bertahan dalam murkanya, tetapi memulai relasi yang baru dengan manusia.

15 Zakaria J. Ngelow, "Turut Membina Indonesia Sebagai Rumah Bersama-Peran Gereja Dalam Politik di Indonesia," Jurnal Jaffray 12, no. 2 (2014): 223.

${ }^{16}$ Emanuel Gerrit Singgih, Iman dan Politik dalam Era Reformasi di Indonesia (Jakarta: PT BPK Gunung Mulia, 2000), 127-129.

17 Ibid, 140.

${ }^{18}$ Henrika, "Pluralitas dan Perdamaian: Ketika Aku dan Engkau Adalah Kita," dalam Multikulutralisme: Kekayaan dan Tantangannya di Indonesia, ed. A. Eddy Kristiyanto dan William Chang (Jakarta: Obor, 2014), 145. 
Masalah komunikasi dapat atasi jika pihak-pihak bersedia membuka diri menerima yang lain. Dengan ini, pembebasan menjadi nyata sebab seseorang bersedia keluar dari benteng menutup diri dari orang lain serta memutus mata rantai lingkaran setan yang membelenggu dirinya. Memutuskan sikap yang selalu didasarkan oleh perbedaan.

Masalah lain pada kerukunan orang Toraja adalah cara mereka memahami struktur kepemimpinan. Dalam perspektif Kristen, kepemimpinan bukan soal kuasa melainkan soal penatalayanan. Gereja dipanggil untuk melayani dunia dalam kerangka teologis kasih Allah kepada dunia melalui gereja. ${ }^{19}$ Konsep gembala dan domba, tuan dan hamba, kepala dan tubuh secara strukturalis menunjukkan pemisahan tetapi dalam relasi intersubjektifitas. Sang pemimpin bertanggungjawab menjamin kehidupan bawahannya, sebaliknya bawahan bertanggungjawab terhadap pemimpinya. Karen Armstrong sebagaimana disarikan oleh Karel Phil Erari, menawarkan empat model kepemimpinan yang baik berdasarkan nilai-nilai Kristiani, yakni harus memiliki sikap belarasa, mampu melihat kepada dunia, belarasa kepada dunia sendiri dan berempati. ${ }^{20}$

Kekeliruan berpikir ditunjukkan oleh mereka yang berusaha "memindahkan" status sosialnya di daerah asal ke daerah yang baru. Mereka tidak menyadari perubahan sosio kultural yang terjadi. Lebih keliru lagi karena yang memertahankan status sosial adalah mereka yang sudah beragama Kristen. Iman Kristen tidak mengenal perbedaan status sosial baik dari segi harta kekayaan terlebih lagi soal status golongan darah. Konsep imago dei jelasjelas menekankan kesetaraan manusia di hadapan Allah. Sesama merupakan mitra dan bukan objek yang harus dikuasai, diperlakukan tidak adil dan didiskriminasi.

Terkait kuasa-menguasai, kekristenan bertolak belakang dengan sistem kelas sosial pada kebudayaan Toraja. Jika berdiri tegak pada Injil, maka bayang-bayang kisah mitologis tentang penciptaan menurut versi Toraja harus ditinggalkan karena tidak dapat diterima oleh iman Kristen. Akan tetapi jika berdialog dengan budaya, maka perlu dilakukan reinterpretasi makna. Kebudayaan Toraja tidak sekedar melanggengkan kekuasaan pada Ambe, Puang atau Ma'dika (Tuan) sebab para pemimpin dan pemilik strata sosial tinggi di masyarakat memiliki tanggung jawab besar yakni menjamin kehidupan dan kesejahteraan warganya. Makna tanggung jawab sebagai jalan masuk yang dapat digunakan dalam dialog kekristenan dan budaya.

Menata Identitas, Mengusahakan Kehidupan Bersama

Cita-cita awal kerukunan adalah untuk menumbuhkembangkan kebersamaan, dengan demikian kolektifitas yang ingin dikedepankan. Inilah warna unik dari kerukunan yang harus dipertahankan, bahwa identitas politik yang dibangun bukan untuk memisahkan diri dari

${ }^{19}$ Zakaria J. Ngelow, “Turut Membina Indonesia Sebagai Rumah Bersama-Peran Gereja Dalam Politik di Indonesia", 225

${ }^{20}$ Karel Phil Erari, "Kekristenan dan Kepemimpinan Kristen, Sekarang dan Masa Depan," in Teologi Politik: Panggilan Gereja di Bidang Politik Pascaorde Baru, ed. Julianus Mojau, Zakaria J. Ngelow dan John Campbell-Nelson (Makassar: OASE Intim, 2013), 213. 
masyarakat. Identitas digunakan untuk menampakkan keterlibatan kelompok dalam masyarakat.

Belajar dari model belarasa yang berusaha dikembangkan oleh kerukunan, maka perlu memperluas sikap belarasa kepada anggota lain di luar komunitas, yakni anggota masyarakat yang berhadapan dengan tekanan hidup maupun masalah sosial lainnya. Dengan begitu, orang Toraja yang beragama Kristen akan terlibat langsung mengembangkan gaya hidup yang sesuai Injil Yesus Kristus.

Sekalipun aksi-aksi sosial terus dilakukan, ternyata tujuan utama yang ingin dicapai tidak dipahami dengan baik oleh semua anggota kerukunan. Penyebabnya adalah faktor kegagalan komunikasi. Pemikiran yang sama ada dibalik konflik-konflik yang terjadi sehingga memecah kehidupan bersama. Atas situasi ini, anggota kerukunan yang beragama Kristen perlu mengambil peran sebagai rekonsliator. Mendamaikan yang bertikai dan aktif menyosialisasikan tujuan utama dibentuknya kerukunan, supaya ketimpangan dan perbedaan kepentingan bisa ditekan semaksimal mungkin.

Kesepahaman dan komunikasi merupakan dua kata kunci yang hendaknya diusahakan agar politik identitas yang dikembangkan bukan politik yang menguasai melainkan politik yang menyejahterakan, terhindar dari perilaku diskriminatif dan ketidakadilan. Kesepahaman dan komunikasi dapat diwujudkan melalui dialog. Dialog harus disertai keinginan membangun kesepahaman dan keseimbangan sikap. Semua dilaksanakan demi terwujudnya kepentingan bersama. ${ }^{21}$ Dialog adalah jalan meredakan ketegangan di tengah keragaman. Jalan menuju perdamaian.

Dialog budaya dan agama sulit dipisahkan karena keduanya saling terintegrasi. Agama dipengaruhi oleh budaya, sebaliknya budaya diperlengkapi nilai-nilai luhur agama. ${ }^{22}$ Jalan ini dapat dipakai untuk menyadarkan masyarakat yang masih berusaha memertahankan perbedaan status sosial. Kekristenan mengembangkan konsep persamaan derajat. Oleh sebab itu, setiap orang perlu menyadari hakikatnya di hadapan Allah supaya ia menjadi terbuka dan tidak memegahkan diri kepada sesamanya. Di sisi lain memperlihatkan perkembangan budaya secara dinamis, sehingga tidak ada alasan memertahankan status sosial masa lampau.

Zakaria J. Ngelow menegaskan penolakannya terhadap politik kepentingan Kristen. Gereja hadir bukan untuk memperjuangkan kepentingan Kristen melainkan kepentingan masyarakat yakni keadilan dan kesejahteraan bagi semua orang. ${ }^{23}$ Dengan nada dasar yang sama pertimbangan tersebut dapat menjadi acuan dalam kerukunan orang Toraja. Tujuan utama dibentuknya kerukunan adalah membangun kebersamaan melalui kepedulian sosial. Kerukunan bukan organisasi yang ditujukan untuk kepentingan politik praktis. Namun

${ }^{21}$ Alyosius M. Sutrisnaatmaka, "Dialog: Tantangan Melawan Penyeragaman dan Pemaksaan Kehendak," dalam Multikulutralisme: Kekayaan dan Tantangannya di Indonesia, ed. A. Eddy Kristiyanto dan William Chang (Jakarta: Obor, 2014), 49.

22 Ibid, 59.

23 Zakaria J. Ngelow, "Beberapa Catatan Mengenai Politik Kristen di Indonesia," dalam Teologi Politik: Panggilan Gereja di Bidang Politik Pascaorde Baru, ed. Julianus Mojau dan Zakaria J. Ngelow John Campbell-Nelson (Makassar: OASE Intim, 2013). 
memberi kebebasan kepada anggotanya terlibat dalam ranah politik, baik sebagai calon legislatif dan atau memilih calon tertentu. Tugas pengurus kerukunan yakni mengrahkan agar anggotanya memilih pemimpin yang mampu memperjuangkan keadilan, perdamaian dan kesejahteraan masyarakat.

Efek negatif terlalu besar ketika kerukunan mengarahkan dukungan pada calon tertentu apalagi jika yang dipilih jauh dari tipe pemimpin ideal, yakni pemimpin yang memerhatikan dan melayani rakyatnya. Kerukunan pun harus bertanggungjawab kepada masyarakat atas pilihannya.

\section{Kesimpulan}

Ambivalensi yang terjadi dalam politik identitas etnis Toraja: Pertama, membentuk kerukunan untuk mengupayakan kehidupan bersama sebagai orang yang berasal dari kampung yang sama maupun sebagai suku Toraja. Kedua, politik identitas demi membangun jaringan kekuasaan didasarkan status sosial yang terlihat dari keinginan mereka merebut kepemimpinan di kerukunan. Ada juga yang menggunakan kerukunan untuk mendapatkan kekuasaan di pemerintahan. Dikotomi yang terjadi memperlihatkan sebagian anggota bingung memilih antara belarasa ataukah melanggengkan kapitalisme. Secara teologis, perbedaan dapat diminimalisir dengan dialog. Tujuan dialog adalah membangun sikap saling menghargai, keadilan, kasih dan kebenaran, serta mendorong kepedulian kepada sesama anggota maupun masyarakat.

\section{Referensi}

Alfaqi, Mifdal Zusron. "Memahami Indonesia Melalui Perspektif Nasionalisme, Politik Identitas, Serta Solidaritas.” Jurnal Pendidikan Pancasila dan Kewarganegaraan 28, no. 2 (2015): 111-116.

Alyosius M. Sutrisnaatmaka. "Dialog: Tantangan Melawan Penyeragaman dan Pemaksaan Kehendak." In Multikulutralisme: Kekayaan dan Tantangannya di Indonesia, diedit oleh A. Eddy Kristiyanto dan William Chang. Jakarta: Obor, 2014.

Anselm Strauss dan Juliet Corbin. "Metodologi Grounded Theory Ulasan Singkat." In Handbook Of Qualitative Research, diedit oleh Norman K. Denzin dan Yvonna S. Lincoln, 349-364. Yogyakarta: Pustaka Pelajar, 2009.

Felix Baghi. "Politik Sebagai Kejadian dan Etika Kebenaran (Alain Badiou dan Soal Universalisme)." In Allah Menggugat-Allah Menyembuhkan, diedit oleh Otto Gusti Maddung dan Anselmus Meo Paul Budi Kleden. Maumere: Ledalero, 2012.

Georger Ritzer; Douglas J. Goodman. Teori Sosiologi Modern. Diedit oleh Tri Wibowo Budi Santoso. 6 ed. Jakarta: Kencana Prenada Media Group, 2007.

Habibi, Muhammad. "Analisis Politik Identitas di Indonesia," 2017.

Henrika. "Pluralitas dan Perdamaian: Ketika Aku dan Engkau Adalah Kita." In Multikulutralisme: Kekayaan dan Tantangannya di Indonesia, diedit oleh A. Eddy Kristiyanto dan William Chang. Jakarta: Obor, 2014.

Ira Mirawati. "Manajemen Komunikasi dan Perdamaian Antar etnis." In Komunikasi Kontekstual: Teori dan Praktik Komunikasi Kontemporer. Bandung: Remaja Rosdakarya, 2013. 
John Campbell-Nelson. "Demokrasi Sebagai Misi Gereja." In Teologi Politik: Panggilan Gereja di Bidang Politik Pascaorde Baru, diedit oleh Julianus Mojau dan Zakaria J. Ngelow John Campbell-Nelson. Makassar: OASE Intim, 2013.

John Rawls. Teori Keadilan: Dasar-dasar Filsafat Politik Untuk Mewujudkan Kesejahteraan Sosial Dalam Negara. Diedit oleh Uzair Fauzan dan Heru Prasetyo. Yogyakarta: Pustaka Pelajar, 2006.

Karel Phil Erari. "Kekristenan dan Kepemimpinan Kristen, Sekarang dan Masa Depan.” In Teologi Politik: Panggilan Gereja di Bidang Politik Pascaorde Baru, diedit oleh Julianus Mojau dan Zakaria J. Ngelow John Campbell-Nelson. Makassar: OASE Intim, 2013.

Kristianus. "Politik dan Startegi Budaya Etnik dalam Pilkada Serentak di Kalimantan Barat." Politik Indonesia: Indonesian Political Science Review 1, no. 1 (2016): 87-101.

Muhtar Habodin. "Menguatnya Politik Identitas Dalam Ranah Lokal.” Jurnal Studi Pemerintahan 3, no. 1 (2012): 116-134.

Narottama, Nararya, A A Ayu Arun, dan Suwi Arianty. "Proses pembentukan identitas budaya nasional Dan promosi pariwisata indonesia di eropa ( studi kasus diaspora bali di perancis )." Jurnal Kepariwisaatan dan Hospitalitas 1, no. 2 (2017): 180-195.

Ng. Philipus dan Nurul Aini. Sosiologi dan Politik. Jakarta: RajaGrafindo Persada, 2004.

Singgih, Emanuel Gerrit. Iman dan Politik dalam Era Reformasi di Indonesia. Jakarta: PT BPK Gunung Mulia, 2000.

Zakaria J. Ngelow. "Beberapa Catatan Mengenai Politik Kristen di Indonesia.” In Teologi Politik: Panggilan Gereja di Bidang Politik Pascaorde Baru, diedit oleh Julianus Mojau dan Zakaria J. Ngelow John Campbell-Nelson. Makassar: OASE Intim, 2013.

" "Turut Membina Indonesia Sebagai Rumah Bersama-Peran Gereja Dalam Politik di Indonesia." Jurnal Jaffray 12, no. 2 (2014). 